\title{
Developing Interactive Multimedia Based Learning Media in Improving Students Learning Outcomes for Grade $4^{\text {th }}$ in Elementary School
}

\author{
Rio Parsaoran Napitupulu \\ Postgraduate of Basic Education \\ Universitas Negeri Medan \\ Medan, Indonesia \\ riobonjovi70@gmail.com
}

\author{
Anita Yus \\ Faculty of Basic Education Universitas \\ Negeri Medan \\ Medan, Indonesia
}

\author{
Ratih Baiduri \\ Faculty of Anthropologi Education \\ Universitas Negeri Medan \\ Medan, Indonesia
}

\begin{abstract}
The problem of this research is the lack of students' learning outcomes on Grade $4^{\text {th }}$ in Elementary School, which is to know whether the students' learning outcomes can increase by developing Interactive Multimedia-Based Learning Media. The learning outcome is a process of behavioral change that occurs after following the teaching learning process. Learning outcomes are influenced by some factors including the internal factors that come from the individual itself and external factors that come from the individual's outside. Developing Interactive Multimedia-Based Learning Media used Adobe Flash CS 6. Adobe Flash CS6 which become the favorite and popular animation program that can make the presentation more interesting. This research used expert validation in developing learning media namely media expert, design and material. The device developing model used 4-D which consisted of 4 developing stages namely, define, design, develop and disseminate. The research that has been pre test phase found that all students did not pass the test and in the post test phase, there was 27 or around $90 \%$ students that passed the test. The effectiveness of product is 0.72 with a very high level of product effectiveness. The feasibility of Adobe Flash CS 6 media based on interactive multimedia developed based on the validation result has a very high level of feasibility. Based on the assessment result, the design experts obtained the feasibility 3.75 in the high category. On media experts, the feasibility of 3.33 is very high and the design experts increase the feasibility of 3.36 in the very high category. From the validation result, the feasibility of Adobe Flash CS 6 media based on interactive multimedia is categorized very feasible to use.
\end{abstract}

Keyword : developing, learning media, interactive multimedia, learning outcomes

\section{INTRODUCTION}

Based on the observation result in Elementary School, the problem that was seen is about the less interactive learning that caused the low of students' learning outcomes. The learning media that was used is inadequate and the dominant like using pictures and paper media. To solve the problem, the solution is developing interactive multimedia-based learning media. Interactive multimedia based on Adobe Flash CS 6 is a multimedia graphics and animation program which is created by the Macromedia Company for the purpose of creating interactive and animated web applications that are developed at this time.

This program is widely used to make games, cartoons, presentations and other interactive learning models. Nowadays with the development of technology and knowledge, the learning media has functions to give a more real experience. Students will be encouraged to learn if students have the development of learning styles that are in line with students' learning outcomes. The learning process also will be fun, safe and free of scary atmosphere because learning media is basically used to deliver the material in terms of achieving the goals of learning success.

Based on the explanation above, the researcher interest is to conduct a research with title "Developing Interactive Multimedia-Based Learning Media in Improving Students' Learning Outcomes for Grade $4^{\text {th }}$ in Elementary School."

\section{THEORETICAL FRAMEWORK}

\section{Definition of Learning Outcome}

[1] Learning outcome consists of two words "outcome" and "learning ". The definition of outcome is the achievement of an activity, while learning is done to change someone's behavior in the learning process. The learning outcomes is a process of behavioral change that occurs after following the teaching and learning process that includes cognitive, affective and psychomotor aspects that cannot be separated from the learning objectives.

Definition of Interactive Multimedia 
States interactive multimedia is a control device that can be operated by the user where the user plays a full role in the operation of the media.[2]

Definition of Interactive Multimedia can be concluded that the message device/ combination of various media in the form of text, graphics, audio, and interaction and it is used to deliver messages / information that causes the strong interaction between the sender and recipient of information.

\section{Definition of Adobe Flash CS6}

Adobe Flash CS 6 Macromedia Flash that turn into Adobe Flash is used to have animation and applications that are used to design and create a web and interactive learning media

The Strengths and Weaknesses of Adobe Flash CS 6

Adobe Flash CS 6 is a favorite and popular animation program that contains presentation with an interesting view and the weakness of Adobe Flash CS 6 is that it is not easy to use, especially for beginners because they have to memorize several commands to make interesting presentation and require software that must be installed.".

\section{CONCEPTUAL FRAMEWORK}

The cause of the low learning outcomes is the learning that has delivered still less interactive, so that students who are inactive and less enthusiastic in the learning process cause the low of students' learning outcomes.

Effective learning is closely related to the use and the chosen learning media, it requires carefulness and criteria in choosing the right learning media. The solution is learning media that can be used to involve students in learning and are expected to improve students' learning outcomes is by developing Interactive Multimedia-Based Learning Media for grade $4^{\text {th }}$ in elemantary school.

\section{RESEARCH METHOD}

\section{Types of research}

This research is an educational research and development / R\&D. This study aims to develop multimedia-based learning media software on Keberagaman Budaya Bangsaku subtheme for grade $4^{\text {th }}$ in Elementary School.

\section{Developing Model}

The device developing model 4-D model, which consists of 4 developing stages namely, define, design, develop and disseminate.

\section{Technique of Analyzing Data}

The following are the steps for analyzing validation assessment data instruments, they are:

\section{Calculate the average score}

$$
\mathrm{X}^{-}=\left(\sum \mathrm{x}\right) / \mathrm{n}
$$

Note:

$$
\overline{\mathrm{X}}=\text { score average }
$$

$$
\begin{aligned}
\Sigma x & =\text { number of scores } \\
n & =\text { number of statement items }
\end{aligned}
$$

1. Change the average score into qualitative criteria by referring to the criteria of scoring 4 scale tables. [4]

Data analysis technique

The following are the steps for analyzing validation assessment data instruments, namely:

Calculate the average score

$\mathrm{X}^{-}=\left(\sum \mathrm{x}\right) / \mathrm{n}$

Note:

$$
\begin{aligned}
& \overline{\mathrm{X}}=\text { average score } \\
& \Sigma x=\text { number of scores obtained } \\
& n=\text { number of statements }
\end{aligned}
$$

Change the average score into qualitative criteria by referring to the criteria for rating criteria for scoring 4 scale tables.

Assessment Criteria for Media Experts, Material Experts and Design Expert

\begin{tabular}{|c|c|c|}
\hline No. & Score Range & Category \\
\hline 1 & $\mathrm{X} \geq(\overline{\mathrm{X}}+1 . S B X)$ & Very feasible \\
\hline 2 & $(\overline{\mathrm{X}}+1 . S B X>X \geq \overline{\mathrm{X}}$ & Feasible \\
\hline 3 & $\overline{\mathrm{X}}>X \geq(\overline{\mathrm{X}}+1 . S B X)$ & Less feasible \\
\hline 4 & $\mathrm{X} \leq(\overline{\mathrm{X}}-1 . S B X)$ & Not feasible \\
\hline
\end{tabular}

Mi (mean ideal) $\quad=1 / 2 \times$ (ideal maximal score + ideal minimal score)

Sbi $($ simpangan baku ideal $)=1 / 6 \mathrm{x}($ ideal maximal score - ideal minimal score)

The scale score of the four calculations can be described as follows:

$$
\begin{aligned}
& \overline{\mathrm{X}}=\text { rerata ideal } \\
& =1 / 2 \text { (ideal maximal score }+ \text { ideal } \\
& \text { minimal score) } \\
& =1 / 2(4+1)=2,5 \\
& \text { SBX }=\text { Simbangan baku ideal } \\
& =(\text { ideal maximal score }- \text { ideal } \\
& \text { minimal score) } \\
& =1 / 6(4+1)=0,5 \\
& \text { Very high }=\mathrm{X} \geq(\overline{\mathrm{X}}+1 . \mathrm{SBX}) \\
& =X \geq 25+(1 \times 0,5) \\
& =\mathrm{x}>3 \\
& \text { High }=(\overline{\mathrm{X}}+1 . \mathrm{SBX}>\mathrm{X} \geq \overline{\mathrm{X}} \\
& =2,5+0,5>x \geq 2,5
\end{aligned}
$$




$$
\begin{gathered}
\begin{array}{c}
=3>x \geq 2,5 \\
\text { Low }=\bar{X}>X \geq(\bar{X}-1 . S B X) \\
=2,5+>x \geq(2,5-0,5) \\
=2,5>x \geq 2
\end{array} \\
\text { Very low }=X \leq(\bar{X}-1 . S B X) \\
=x<(2,5-0,5)
\end{gathered}
$$

Analysis of Student Learning Outcomes

$\mathrm{S}=\sum \mathrm{R}-\left(\sum \mathrm{W}\right) /(\mathrm{n}-1)$

Source: Purwanto (2011:190)

Note:

$\mathrm{S}=$ Score sought

$\sum \mathrm{R}=$ number of correct questions

$\sum \mathrm{W}=$ number of incorrect questions

$\mathrm{n}=$ number of options (alternative answer to each question)

$1=$ fixed number

Data Analysis of Product Effectiveness Test

$\mathrm{N}$-gain testing is done to know the increase in learning outcomes between before and after learning, calculated by the formula:

$$
(\mathrm{N}-\mathrm{g})=((\text { gain })) /(\text { gain }) \_ \text {maks }=(\text { s_post-s_pre }) /(100-\text { s_pre })
$$

Source: Hake (Muldin, 2015: 159).

\section{RESEARCH RESULTS}

The feasibility of Adobe Flash CS 6 media based on interactive multimedia developed based on the results of validation has a very high level of feasibility. Based on the results of assessment, criticism and suggestions from material experts, media experts and design experts. The design experts obtained the feasibility of 3.75 in very high category. In media experts obtained 3.33 in the very high category of feasibility and in design experts increase the feasibility of 3.36 in very high category.

Based on data analysis conducted the completeness of learning that has been pre-test phase all students did not pass and the in the pots test, there were 27 students or $90 \%$ were passed.

Next the learning effectiveness obtained N-Gain is 0.72 with a very high level of effectiveness product

\section{CONCLUSIONS}

Some conclusions that can be drawn from this research are:

1. The learning completeness that has been done, pre-test phase all students did not pass the test and in the posttest 27 or $90 \%$ passed the test.

2. The product effectiveness is $\mathrm{f} 0.72$ with a very high level of

3. The feasibility of Adobe Flash CS 6 media based on interactive multimedia developed based on the results of validation has a very high level of feasibility. Based on the results of assessment, criticism and suggestions from material experts, media experts and design experts. The design experts obtained the feasibility of 3.75 in very high category. In media experts obtained 3.33 in the very high category of feasibility and in design experts increase the feasibility of 3.36 in very high category. Based on the Validation results, the feasibility of Adobe Flash CS 6 media based on interactive multimedia is categorized as very feasible to use.

\section{REFERENCES}

[1] Purwanto. 2011. Evaluasi Hasil Belajar. Yogyakarta : Pustaka Belajar

[2] Daryanto. 2017. Media Pembelajaran. Bandung. CV. YRAMA WIDYA

[3] Sudjana, Nana. 2010. Penilaian Hasil Proses Belajar Mengajar. Bandung: PT.Remaja Rosdakarya.

[4] Mardapi, Djemari. 2008. Teknik Penyusunan Instrumen Tes dan non Tes. Yogyakarta: Mitra Cendikia. 